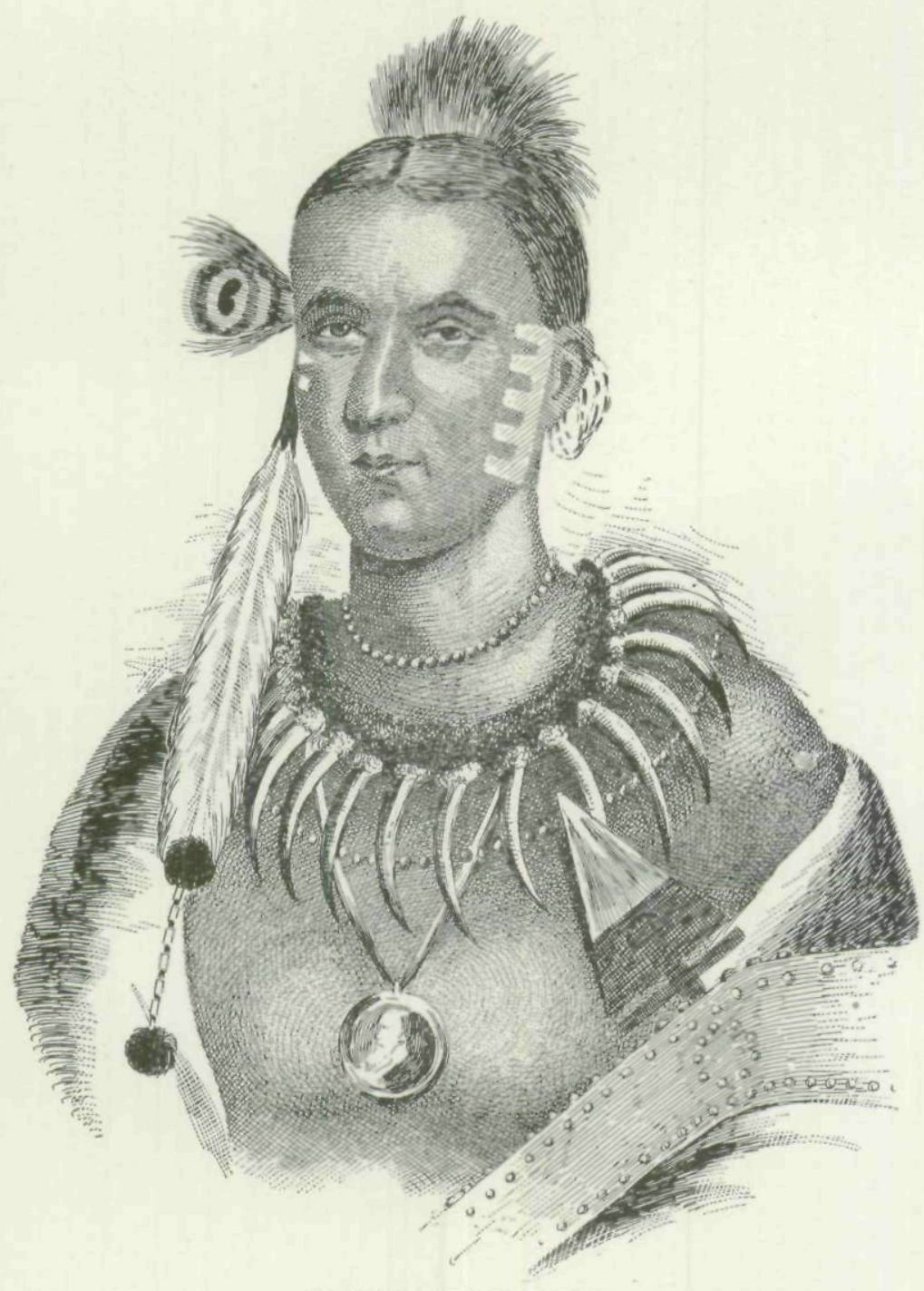

MA-HAS-KA, OR WHITE CLOUD,

An Iowa chief, for whom one of our large and populous counties was named. 


\title{
IOWA IN UNORGANIZED TERRITORY OF THE UNITED STATES.
}

\author{
August 10, 1821-June 28, 1834.
}

BY REV. WILLIAM SALTER, D. D.

Upon the admission of the State of Missouri into the Union, the country north of that State, and the residue of the Louisiana Purchase north of $36^{\circ}, 30^{\prime}$, were left without law or government, except the prohibition of slavery and laws to regulate the Indian trade. Traders and army officers, however, as occasion served, still carried slaves into the territory.

The soil of Iowa continued in the occupancy of a few Indian tribes, who lived in villages on banks of rivers, and often fell foul of one another as they roamed over the prairies in hunting expeditions. There were about six thousand Sacs and Foxes with a thousand Ioways in eastern and central Iowa, one or two thousand Otoes, Pawnees and Omahas in western Iowa, and roving bands of Sioux in northern Iowa, numbering a thousand more; in all, about ten thousand souls. War was their native element, the ideal of savage life. A skulking band of Sacs under Pash-e-pa-ha and Black Hawk, in May, 1823, for some real or imagined wrong, surprised and nearly exterminated an Ioway village upon the Des Moines river at Iowaville, while the braves of the village were at their sports and games, without arms.

During this period the American Fur Company monopolized the Indian trade, and made exorbitant profits. Regardless of the laws prohibiting the introduction of intoxicating liquor into the Indian country, they smuggled it in under artful devices. Congress fostered the Santa Fe trade, and the rich fur trade of the upper Missouri and the Rocky Mountains, but made no provision for the prairie country between the Mississippi and the Missouri. President Monroe in his message, December, 1824, suggested the removal 
to this region of the northern Indians who were east of the Mississippi, with schools for their industrial education, as had been recommended by the secr-tary of war, John C. Calhoun. President Jackson made a similar recommendation in his message to congress in 1829. Had these suggestions been carried out, what is now Iowa might have been for northern Indians what the Indian territory has been for the southern Indians. But the Indians who held this region scouted civilization and an industrial life; and the Winnebagoes and the Pottawattamies, who were removed into the region at the close of this period, profited little by their removal. The condition of children and old people among the Indians was extremely pitiable, as reported by the Commissioner of Indian Affairs, William Clark, in 1826:

During several seasons in every year they are distressed by famine in which many die, and the living child is often buried with the dead mother. They have neither hogs nor cows, and do not want them, because they would eat up their little patehes of corn which are without fences, and because, as the whole nation go out to hunt twice a year, they want nothing but horses and dogs whieh aecompany them. In these expeditions the aged and infirm, when unable to keep up, are frequently left to die.

Had the different tribes lived at peace among themselves, and with the United States, they might have remained where they were. There was no disposition to acquire their lands at that time on the part of the United States. Such a disposition was expressly disclaimed by the agents of the Government, Lewis Cass and William Clark. Large tracts of land east of the Mississippi were still unsettled. There seemed no necessity, as there was no demand, for more land to be thrown open to the white people. At the same time the State of Missouri desired the removal of the Sac and Fox and Ioway Indians from the lands they held or claimed in that State. A deputation of the chiefs and head men of those tribes was taken to Washington, D. C., in 1824, and treaties were made with them for the cession of those lands to the United States. The famous Sac chiefs, Pash-e-pa-ha and Keokuk, the Fox chief, Tama, and the Ioway chief, Mahaska, 


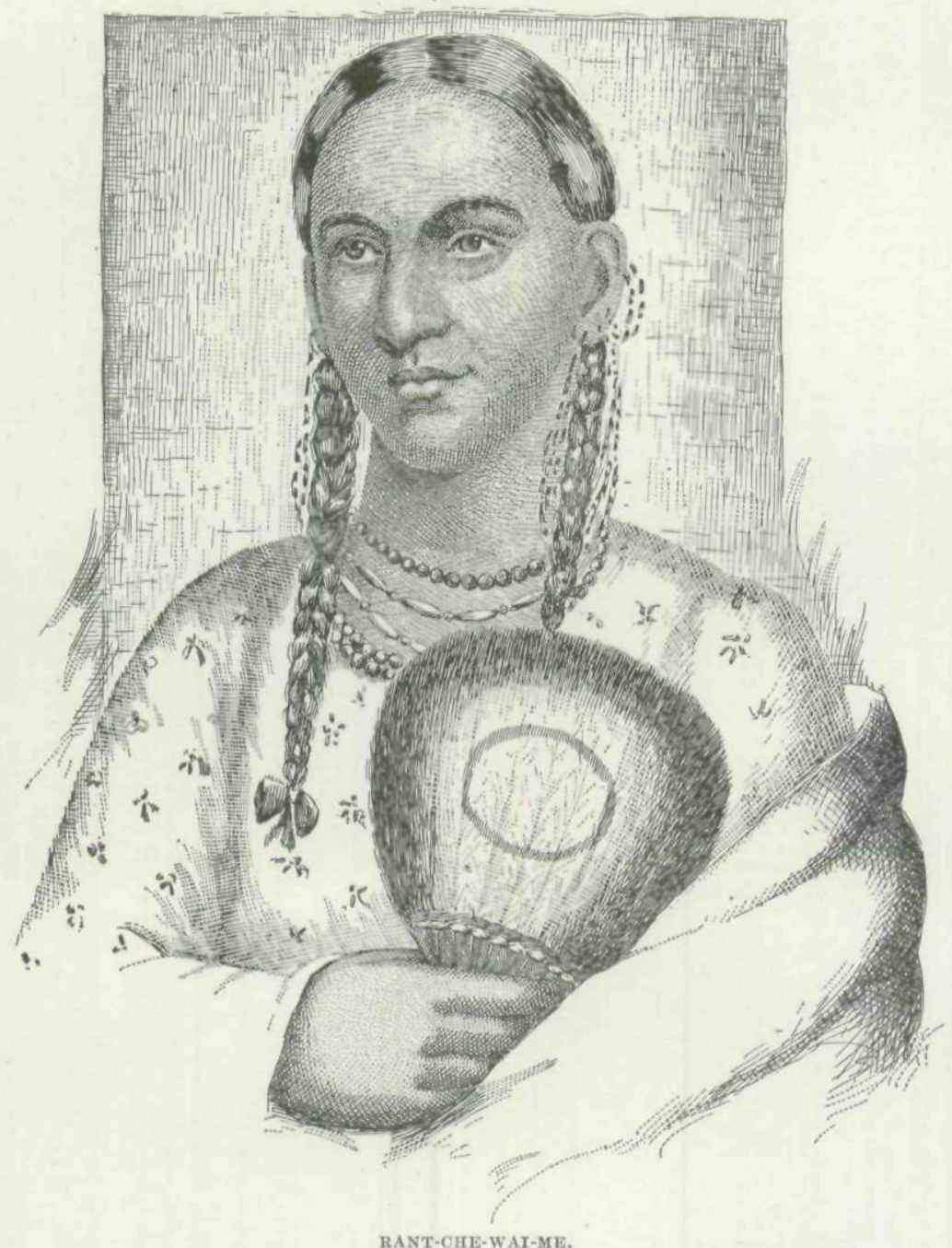

"The Female Flying Pigeov," wife of the Iowa Chief Ma-has-ka. She was one of the most beautiful Indian women of Iowa Territory, distinguished also for other high qualities. 
were in the deputation. Flying Pigeon, Mahaska's wife, accompanied him. He had refused her request to go, but she followed him to St. Louis, and with tomahawk in hand claimed her right to keep him company. He yielded to her importunity. A woman of handsome presence and noble bearing, she was feted at the White House as an Iowa princess, and her portrait painted for the Indian Gallery. After the cession took effect, January 1, 1826, those tribes were confined to their lands in what is now Iowa, save that Black Hawk and his band, who were known as the Sacs of Rock river, remained east of the Mississippi. The treaty with the Sacs and Foxes also provided that "the small tract of land lying between the rivers Des Moines and Mississippi, and the section of the State boundary line between the Mississippi and the Des Moines, is intended for the use of the halfbreeds belonging to those nations;" according to the sentiment in the Indian mind that care and protection were due to any who inherited their blood.

In those years the Sacs and Foxes kept up their hereditary war with the Sioux. In order to promote peace and establish boundaries between them, as well as between all the tribes from the Lakes to the Missouri river, invitations were sent out to the chiefs and head men of those tribes to assemble at Prairie du Chien in the summer of 1825, and in a spirit of mutual conciliation accomplish those objects. It was a great assemblage. Eva Emery Dye describes it in "The Conquest- the True Story of Lewis and Clark," with graphic pen:

Prairie du Chien was alive with excitement. The village and both banks of the river above and below were eovered with high-pointed buffalo tents. Horses browsed upon the bluffs in Arabian abandon. Below, tall and warlike Chippewas from Superior and the valley of the St. Croix, and Winnebagoes from Fox river and the Rock river, jostled Menomonees, Pottawattamies and Ottawas, from Lake Michigan and Green Bay.

Agent Taliaferro from the Falls of St. Anthony made the grand entry with the Sioux, four hundred strong, drums beating, flags flying.

Over from Sault St. Marie the learned Schooleraft had brought one hundred and fifty Chippewas. 
Keokuk, the Watchful Fox, with his Sacs and Foxes, was the last to arrive. They had camped on an island below to paint and dress, and came up the river in full war costume, singing their battle-song. It was a thrilling sight when they came with spears and battle-lances, casting bitter glances at their ancient foe, the Sioux. Nearly nude, with leather warflags flying, and beating tambourines, the Sacs landed in compact ranks, breathing defiance. From his youth Keokuk had fought the Sioux; bold, martial, frowning, he shook his war lance at them.

At the signal of a gun, every day at ten o'clock, the chiefs assembled.

"Children," said Governor Clark, "your great Father, the President, has sent us here not to ask anything from you, not the smallest piece of your land. We have come for your good. Your great Father has been informed that war is carried on among his red children,- - the Sacs, Foxes, Ioways, on the one side, the Sioux on the other; and that the wars began before any of you were born.

"Heigh! Heigh!" broke forth the silent smokers.

"Heigh! Heigh!" exclaimed the warriors.

"Heigh! Heigh!" echoed the vast assembly.

"Your Father thinks there is no cause for you to continue at war. There is land enough for you to live and hunt on, and animals enough. Why not peacefully follow the game, and provide for your families? Why do you send out war parties to destroy each other? The Great Spirit made you all of one color, and placed you upon the land. You ought to live in peace as brothers of one family. Your great Father has heard of your war-songs and war-parties. They do not please him. He wants his red children to bury the tomahawk.

"Children, your wars have come from your having no boundaries. You do not know what lands belong to you, and your people follow the game into land̉s claimed by other tribes."

"Heigh! Heigh! Heigh!' shouted all the Indians.

Governor Lewis Cass, of Michigan Territory, spoke:

"Children, your great Father does not want your land. He wants to establish boundaries and peace among you. Children, you are hungry. We will adjourn for two hours."

"Heigh! Heigh! Heigh!" rolled the chorus of a thousand voices.

As to an army, rations were distributed; beef, bread, corn, salt, sugar, tobacco. Each ate, ate, ate,- till not a scrap was left to feed a hummingbird.

Wabashaw, Red Wing, and Little Crow were the great Sioux chiefs, as their fathers of the same name had been before them. "Boundaries!" they said; "we know not the word." The idea was foreign to an Indian mind. "We are all one people. I claim no lands in particular," said Mahaska, the Ioway chief, whose bands from the discovery of the country had sped their canoes from river to river over the whole region from Lake Michigan to the Missouri, and from the St. Peter's to St. Louis. "I never heard that any one had an exclusive right to land," said another chief. "I have a tract of country where I was born, and now live," said Red Bird, the 
Winnebago, dressed in white deerskin and scarlet, and glovefitting moceasins, the dandy of his tribe, "but the Foxes claim it, and the Sacs, and the Ottawas. We use it in common."

Chiefs sat on the ground, and marked off on the earth the rivers that bounded the lands they claimed, and maps were drawn on birch bark, outlining the hunting grounds of the different tribes. The lines crossed and recrossed each other.

"Here are the causes of your wars," said the United States Commissioners. "It is better for you to give up your disputes, and agree among yourselves upon a limitation of your boundaries."

After much discussion, and fierce and fiery talks at one another, the different tribes agreed to listen to the Commissioners, to adjust their boundaries, and make a firm and perpetual peace with one another and with the United States.

To speak only of what relates to this history,- the Upper Iowa river from its mouth to the source of its left fork, thence crossing the Red Cedar in a direct line to the upper fork of the Des Moines, thence in a direct line to the lower fork of the Big Sioux river, and down that river to the Missouri, was made the boundary line between the Sioux and the Sacs and Foxes. The claim of the Ioways to a portion of the country with the Sacs and Foxes was acknowledged, also the claim of the Otoes to a portion of the country on the Missouri river. The Sacs and Foxes relinquished all claim to land east of the Mississippi, and acknowledged the reservation made for the half-breeds in 1824 . It was further understood that no tribe should hunt in the limits of another without its assent, and that in case of difficulties all the tribes should interpose their good offices to remove them.

Of the one hundred and thirty-four chiefs who signed this treaty, twenty-six were Sioux, twelve were Sacs, sixteen were Foxes, and ten were Ioways. President John Quincy Adams in his first annual message, December 6, 1825, referred to this treaty as "an adjustment of boundaries, and pledges of permanent peace between tribes which had been long waging bloody wars against each other."

The Indians, however, could not keep their agreement. They had no sense of treaty obligations. "To touch the goose-quill" meant nothing. The slightest provocation, an 


\section{imaginary affront, called for the scalp of their enemies.} They were soon at war again. The Sioux still came down on their old enemies.

"In May, 1830," says an eye-witness, "I visited Prairie du Chien, and was a guest of Joseph Rolette, agent of the American Fur Company. One evening we were startled by the reports of firearms on the Mississippi, succeeded by sounds of Indian drums and savage yells. About midnight we were aroused by footsteps on the piazza and by knocking on the doors and shutters. Mr. Rolette went out to ascertain the cause, and was informed that a bloody battle had been fought, and the visitors were the victors, and called up their trader to obtain spirit-water for a celebration. Their wants were supplied. The warriors kept up a horrible pow-wow through the night with savage yells. In the morning we heard the particulars of the fight, and during the day witnessed a most revolting exhibition.

"On the day before the battle, some twenty Sioux joined by a few Menomonees encamped on an island opposite Prairie du Chien. The Sioux had information that a party from the Fox village at Dubuque were to visit Prairie du Chien, and would encamp for the night near the mouth of the Wisconsin river. That afternoon the Sioux party descended the Mississippi and hid in thick bushes near where their victims would encamp. Between sunset and dark, the unsuspecting Foxes, - one old chief, one squaw, a boy of fourteen years, and fifteen warriors,-came up and disembarked. After they had landed, and were carrying their effects on shore, leaving their guns and war-clubs in the canoes, the party in ambush sprang to their feet and fired upon the Foxes. All were slain, except the boy who escaped down the river. Hands, feet, ears, and scalps were cut off, and the heart of the chief eut from his breast, as trophies.

"The next day the victors accompanied by a few squaws paraded the streets with drum and rattle, displaying on poles the sealps and dismembered fragments of their victims. The whole party was painted in various colors, wore feathers, and carried their tomahawks, war-clubs, and sealping knives. Stopping in front of the principal houses in the village, they danced the war-dance and the scalp-dance with their characteristic yells. The mangled limbs were still fresh and bleeding; one old squaw carried on a pole the hand with a strip of skin from the arm of a murdered man, she keeping up the death-song, and joining th the scalp-dance. After this exhibition, which lasted two or three hours, the warriors went to a small mound, about two hundred yards from Mr. Rolette's residence, made a fire, roasted the heart of the old chief, and divided it into small pieces among the warriors who devoured it.

"This occurred in a town of six hundred inhabitants, under the walls of the United States garrison, within musket shot of the fort. Neither civil nor military authority made any effort to prevent it. In the afternoon the Sioux embarked in their canoes to return to their village."*

*Wis. Hist. Coll., ix, 324-6. 
Not long afterwards a war party was formed in the Fox village to avenge the murder. Wailings and lamentations for the dead gave way to savage yells. With blackened faces, chanting the death-song, the party entered their canoes. Arriving at the bluffs opposite Prairie du Chien they discovered a Menomonee encampment spread out on the ground, nearly under the guns of Fort Crawford. The Foxes lay in ambush till midnight, when girded with tomahawk and scalping knife they swam the river and stole upon the foe. In the first lodge an old chief sat by a smouldering fire, smoking his pipe in sleepy silence. They dispatched him without making a disturbance, and pursued their bloody work from lodge to lodge until the whole encampment with the women and children met the same fate. Then with a yell of satisfaction and revenge they took to the canoes of their victims, bearing aloft the trophies of victory. Upon reaching their village, they held their orgies and danced the scalp-dance. But fearing a swift retaliation, they concluded to abandon their village, and seek a safer place among other bands of their tribe, and near the Sacs. They settled where the city of Davenport now stands. Eye-witnesses reported seeing them as they came down past Rock Island, their canoes lashed side by side, the heads and scalps of their enemies set upon poles. They landed with shouts of triumph, singing war-songs, displaying the scalps and ghastly faces of the slain. The new village was called Morgan, after their chief, a half-breed of Scotch and Fox blood.*

Soon after the Foxes had deserted their village at Dubuque, adventurers from Galena, Illinois, went over there to explore the mines and make claims. Lucius H. Langworthy says:

We crossed the Mississippi (June, 1830,) swimming our horses by the side of a canoe. A large village was at the month of Catfish creek, solitary, deserted. About seventy buildings eonstructed with poles and bark remained. The council-house contained furnaces in which kettles had

*Annals of Iowa, 1563, pp. 35-6. 
been placed to prepare feasts; but the fires had gone out. On the inner surface of the bark were paintings, done with considerable skill, representing the buffalo, elk, bear, and other animals, also wild sports on the prairie, and feats of warriors in bloody fray, - a rude record of national history. Could the place have been preserved, it would have been an interesting relic, but it was burned down by vandal hands in the summer.

While the adventurers were mining, and working some valuable lodes, Captain Zachary Taylor, U. S. A., came down from Fort Crawford and ordered them off, as the country belonged to the Indians. The miners demurred. They said: "The country is vacant and we will stay." The captain replied, "We will see about that." Returning to Prairie du Chien, he sent down a detachment of troops to remove the intruders, and they left. Whereupon some of the Foxes, finding that they would be protected by U. S. troops, returned to their village, and made a large profit from the mines which the men from Galena had opened.

Some years earlier, several bands of the Sacs and Foxes, pursuant to the treaty of 1804 , had removed from the east side of the Mississippi to the west side. Keokuk, Wapello, and Poweshiek had planted villages upon or near the Iowa river. Tama had moved from Henderson creek, Illinois, to Flint creek, nearly opposite. But Black Hawk, though requested by U. S. agents, refused to leave. He said, "My reason teaches me that land cannot be sold. Nothing can be sold but such things as can be carried away." In 1829 and 1830 President Jackson ordered the removal of the Indians from the lands ceded in 1804 . The United States had surveyed and sold most of those lands. Part of them were "bounty lands" to soldiers of the war of 1812. Purchasers claimed possession. Altercations and disputes arose between Black Hawk's band and the settlers. There were misunderstandings and depredations on both sides.

The Sacs and Foxes and the Sioux continuing at war with each other, a council of their chiefs was convened at Prairie du Chien, July, 1830, at which it was agreed to erect a barrier between them in order to keep them apart. The Sioux 
ceded to the United States a tract twenty miles wide north of and adjoining the boundary line between them and the Sacs and Foxes fixed in 1825, and the Sacs and Foxes ceded to the United States a similar tract twenty miles wide south of that line. These were called "neutral grounds." Its southern boundary on the Mississippi was indicated by a "Painted Rock," marked with figures of wild animals and hieroglyph. ics, to serve as a notice to all parties.

At the same council, by the same treaty, the Sacs and Foxes, Ioways, Missourias, Omahas, Otoes, and bands of Sioux, joined in ceding to the United States all their right and title to what is now western Iowa, that is, west of "the high lands between the waters falling into the Missouri and Des Moines rivers and of the dividing ridge between the forks of Grand river to the source of Boyer river, and thence in a direct line to the upper fork of the Des Moines." Thus the Indian title to western Iowa was extinguished, and these "high lands" and this "dividing ridge" were acknowledged as the western boundary of the lands of the Sacs and Foxes and Ioways.

In 1831, General Gaines, with U. S. troops, and Governor Reynolds, of Illinois, with a force of militia, came to Rock Island, and demanded of Black Hawk that he remove west of the Mississippi. Black Hawk was sullen and spiteful. The interpreter said to him, "Your father asks you to take a seat." "My father!" replied the petulant chief, repeating what Tecumseh said twenty years before to General Harrison, "The sun is my father; the earth is my mother; I will rest upon her bosom." At this crisis Keokuk made an effort to conciliate Black Hawk. He advised him to take a reasonable view of the situation, and persuaded him once more to "touch the goose-quill." Says the U. S. army officer, who drew up Black Hawk's engagement to remove:

There were in attendance about fifty chiefs and warriors. All being seated in due form, I read the treaty, sentence by sentence, interpreted by Antoine LeClaire. I called up Black Hawk to affix his sign manual to the

VoL. VI-13. 
paper. He arose slowly and with dignity, while in the expression of his fine face there was a deep-seated grief and humiliation that no one could witness unmoved. When he reached the table, I handed him a pen, and pointed to the place where he was to affix his mark. He took the pen, made a large bold cross with force; then returning it politely, he resumed his seat. It was an imposing ceremony; scarcely a breath was drawn by any one. Thus ended the scene, one of the most impressive of the kind $I$ ever looked upon.*

General Gaines made a present to Black Hawk and his band of a large quantity of corn for their subsistence, and of five thousand dollars' worth of goods, and they immediately removed to the west side of the Mississippi, under promise not to return to the east side without permission from the Governor of Illinois or the President of the United States.

Black Hawk might well have been content on the west side of the Mississippi, and planted his villages and cornfields in some of the rich valleys of Iowa, as other chiefs had done. The country his people still held was of vast extent. All the Sacs and Foxes with the Ioways numbered but a few thousand souls. They had the protection of the United States in the possession of about two hundred miles square of land as fair as any beneath the sun. Had Black Hawk staid upon these lands, he would not have been disturbed for the rest of his life. But insensible to these considerations, he nursed his grief and his vexation. Reckless of promises, confident of aid and support from other tribes, and even from his British father, he laid his plans to return to Rock river. Keokuk opposed them, and said to his people:

Braves! I am your chief, to rule you as a father at home, and lead you in war, if you are determined to go; but in this war there is only one course. The United States is a great power; and unless we conquer, we must perish. I will lead you on one condition only, that we put our old men and the women and ehildren to death, and resolve when we cross the Mississippi never to return, but perish among the graves of our fathers.

The majority listened to Keokuk and heeded his warnings; but others, the young braves especially, were eager to go on the war-path, and rallied to Black Hawk. It was

*Letters from the Frontiers, by George A. McCall, p. 241. 
while U. S. troops were on their way up the Mississippi to enforce a demand for the punishment of the Foxes who had murdered the Menomonees, that Black Hawk with several hundred warriors on horseback, and a retinue of followers, crossed the Mississippi at the Yellow Banks (Oquawka), on the 6th of April, 1832, to the terror of the settlers upon the Illinois frontier. His forces were recruited by some Winnebagoes and Pottawattamies. He raised the British flag. The whole number of Indian warriors was variously estimated at from six to eight hundred. The Black Hawk war was carried on in Illinois and in Wisconsin (then a part of Michigan territory), and belongs to the history of those states. Conspicuous for his valor and energetic services in defeating Black Hawk was Henry Dodge. His bravery and daring at the battles of Pecatonica, Wisconsin Heights, and Bad Axe, led his compatriots to name him "Captain of aggressive civilization. Hero of the Black Hawk war." By his influence over some Winnebago chiefs he secured the capture of Black Hawk, when in flight to Canada.*

As some of the Winnebagoes and Pottawattamies abetted the war, those tribes shared in the disastrous consequences which fell to Black Hawk. The people on the frontier called for their removal. Black Hawk went to war in order to keep the white man out of the country; the result of the war was to bring the white man in. It hastened the settlement of northern Illinois and of Wisconsin. The founding of the states of Wisconsin and Iowa, and of the city of Chicago, would have been delayed indefinitely but for this war. Thirty-five years afterward, it was said at the annual meeting of the Historical Society of Wisconsin:

Those border wars may seem trivial, but when we consider Wisconsin as it then was, with roving bands of Indians the terror of the few whites, it will be seen that the settlement of the country depended upon the battle fields of the Black Hawk war; instead of being uninteresting spots, they are the birthplace of our State.

${ }^{*}$ A sketch of the services of Henry Dodge in the Black Hawk war is in the Iowa Historical Record, vi. 391-423. 
The Winnebagoes were convened in a council of their chiefs and head men at Rock Island, September 15, 1832, when they ceded to the United States all their lands in Illinois and Wisconsin, and the United States in exchange ceded to them the "Neutral Ground," described above, and agreed to pay them annually for twenty-seven consecutive years the sum of ten thousand dollars, to establish a school for their children voluntarily sent to it, and to make other provisions for their benefit. The Winnebagoes engaged to deliver up certain individuals who were accused of murdering citizens of the United States in the late war, and to remove to the "Neutral Ground" on or before June 1, 1833.

The removal of the Pottawattamies was arranged later, under a treaty made at Chicago, September 26, 1833, by which five million acres in western Iowa were assigned them. The United States met the expense of their removal, of their subsistence for one year after their arrival at their new home, and provided for the payment of more than eight hundred thousand dollars, to be expended for the erection of mills, and for other useful objects, and in annuities to them.

Soon after the capture of Black Hawk, the principal Sacs and Foxes who had not joined him, Keokuk, Pa-she-pa-ha, and seven other Sacs, Wapello, Tama, Poweshiek, and twenty-one other Foxes, were summoned to a council with Commissioners of the United States, Major General Winfield Scott, and Governor Reynolds, of Illinois. They met September 21, 1832. In opening the council, General Scott reproached the Indians in stern language that they had not restrained Black Hawk from going to war; and the Commissioners demanded as indemnity for the millions the war had cost the United States, and to secure the future safety of the invaded frontier, that they cede to the United States "a portion of their superfluous territory," bordering on that frontier. The Indians assented, and ceded to the United States a strip of territory lying along the Mississippi from the northern boundary of the State of Mis- 


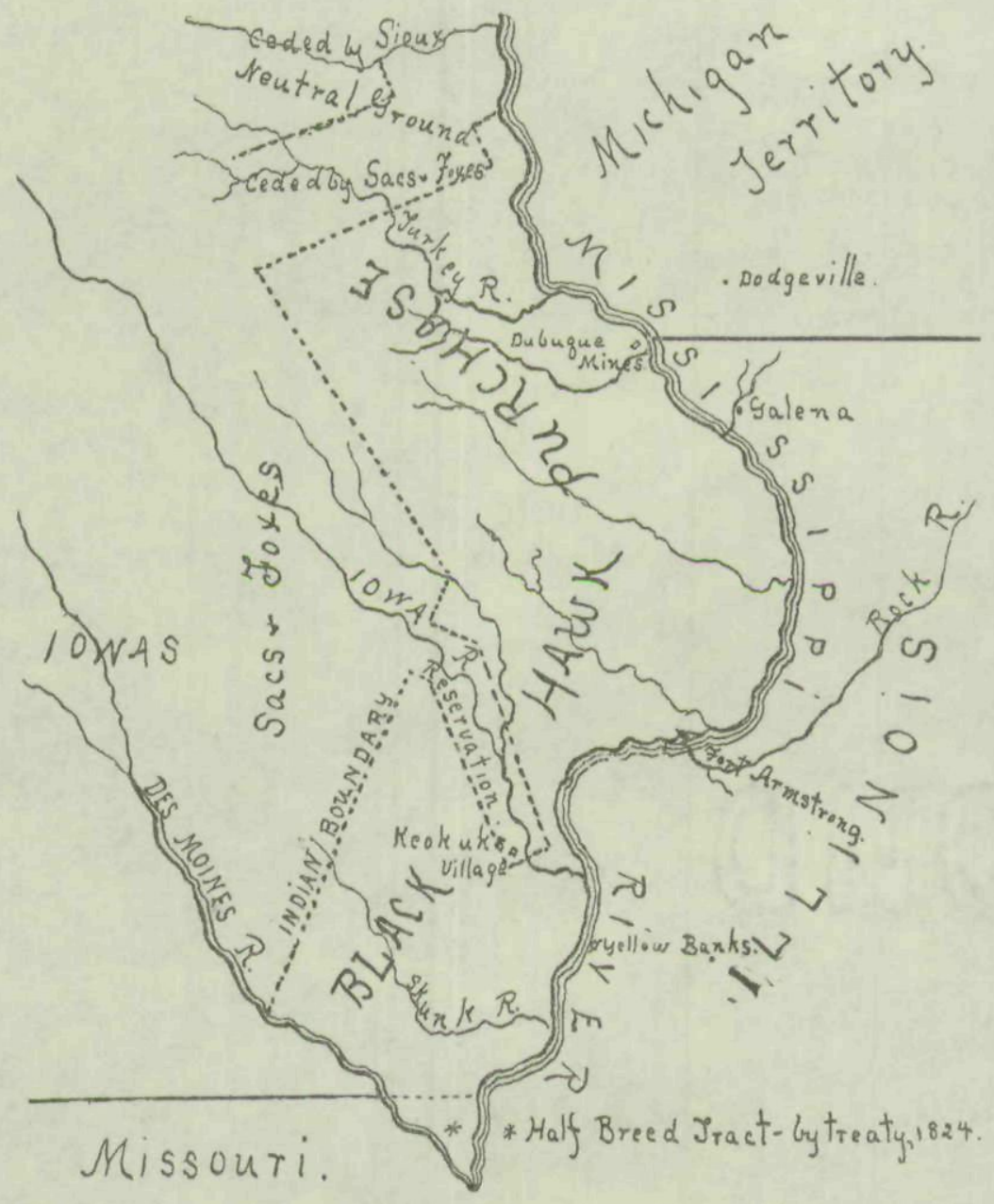

THE BLACK HAWK PURCHASE.

$$
\text { by treaty of Sept.21紫1832. }
$$

Carrie B Mairn. 
souri to the "Neutral Ground," part of it extending fifty miles west, part of it forty miles. A reservation for the Indians in this cession was made of four hundred square miles, on both sides of the Iowa river, and embracing the villages of Keokuk and Wapello. In consideration of the extent of the cession, the United States agreed to pay annually to the Sacs and Foxes for thirty years the sum of twenty thousand dollars. It was further agreed that the United States should hold Black Hawk, his two sons, and eight other warriors as hostages for the future good conduct of the late hostile bands. They were then in confinement at Jefferson Barracks. Washington Irving was in St. Louis at the time, and went to see them. He wrote, September 16, 1832:

The redoubtable Black Hawk, who makes such a figure in our newspapers, is old. emaciated, and enfeebled. He has a small, well-formed head, an aquiline nose, a good expression of eye. His brother-in-law, the prophet, a strong, stout man, much younger, is considered the most culpable agent in fomenting the late disturbance; though I find it difficult, even when so near the scene of action, to get at the right story of these feuds.

After the treaty was concluded, General Scott invested Keokuk, the other chiefs consenting, with the rank and gold medal of head chief, and gave them all a grand dinner. When night came on, batteries of rockets and fire-balls from mortars emblazoned the sky, amid savage shouts of astonishment and delight. Keokuk joined in presenting a pantomime of Indians on the war-path, surprising and capturing an enemy. A war-dance followed; in the carouse young army officers made merry with the braves, dancing together. The ground on which the treaty was made was upon the west bank of the Mississippi, the site of the city of Davenport. At the close of the festive scenes the Indians dispersed cheerful and contented. The ceded lands were called for a time "Scott's Purchase," but later "The Black Hawk Purchase," from the war which bore his name. The Indians agreed to remove from them on or before June 1, 1833. The name of Scott is retained in that of the county which holds the ground where the treaty was made. The Indians 
left the "Purchase," as they agreed, for their lands further west, except that those who occupied the "Reservation" remained upon it.

The United States troops who were protecting the Foxes at the Dubuque mines were sent against Black Hawk when the war broke out; at the same time the Foxes went and joined Black Hawk. In the desertion of their village, miners from the east side of the Mississippi again crossed over, and resumed operations at Dubuque, but were ordered off later by military authority; as were adventurers who made claims at Flint Hills (Burlington), Fort Madison and other points; the country belonging to the Indians until the day agreed upon for their removal.

Black Hawk and the other hostages were confined at Jefferson Barracks until April, 1833, when they were sent to Fortress Monroe. At Washington the President, Andrew Jackson, received them in a kind spirit. He told them that the time of their detention would depend upon the conduct of their people, and it was ascertained that their bad feelings were banished, and that they were to remain in Fortress Monroe until he gave them permission to return to their homes.

Black Hawk made his explanation as to the cause of the war, and said that his people were exposed to attacks by the Sioux and Menomonees, and he wanted to return to take care of them.

The President replied that he was apprised of the circumstances of the war, and it was unnecessary to look back to them. It was his purpose to secure the observance of peace, and prevent the frontiers from being again stained with blood. They need feel no uneasiness about the Sioux and Menomonees. He meant to compel the red men to be at peace with each other, as well as with their white neighbors. He had taken measures with this view, and when it was ascertained that they were effectual,- - when the tribes learned that the power they attempted to contend with was equally 
able and disposed to protect the peaceful, and to punish the guilty, and when assured that Black Hawk's people in particular were convinced of this, and were disposed to observe the terms of peace granted to them, then they would be restored to their families.

- The President then gave his hands to the chiefs and dismissed them.

The next month Keokuk asked for the release of the prisoners, and pledged himself for their good behavior, and the Government arranged to send them home. Upon their homeward route they had another interview with the President, at Baltimore. He said to them:

My children, when I saw you in Washington, I told you that you had behaved very badly in raising the tomahawk, and in killing men, women, and children upon the frontier. Your conduct compelled me to send my warriors against you; your people were defeated, and your men surrendered, to be kept until I should be satisfied that you would not try to do any more injury. I told you I should inquire whether your people wished you should return, and whether if you did return, there would be any danger to the frontier. General Clark and General Atkinson have informed me that Keokuk, your prircipal chief, has asked me to send you back, and the rest of your people are anxious you should return. Your chiefs have pledged themselves for your good conduct, and I have given directions that you be taken to your own country. You will be taken through some of our towns. You will see the strength of the white people. You will see that our young men are as numerous as the leaves in the woods. What can you do against us? You may kill a few women and children, but such a force would soon be sent against you as would destroy your whole tribe. Let the red men hunt, and take care of their families; but I hope they will not again raise their hands against their white brethren. We do not wish to injure you. We desire your prosperity and improvement. But if you again plunge your knives into the breasts of our people, I shall send a force which will severely punish you. When you go back, listen to the counsels of Keokuk and the other friendly chiefs. Bury the tomahawk, and live in peace with the frontiers. And I pray the Great Spirit to give you a smooth path and a elear sky to return.

\section{Black Hawk answered:}

My Father: My ears are open to your words. I am glad to hear them. I am glad to go back to my people. I want to see my family. I did not behave well last summer. I ought not to have taken up the tomahawk. My people have suffered a great deal. When I get back I will remember your words. I will not go to war again. I will live in peace. I shall hold you by the hand. 
The party were taken under the conduct of Major Garland, of the U. S. army, through the cities of New York, Buffalo, Cleveland, and Detroit, by way of Green Bay and the Wisconsin river, to Rock Island, where a large company of chiefs and braves assembled to welcome them. Keokuk said:

The Great Spirit has been kind to them. He bad listened to their prayers. They ought to be thankful. They had petitioned their great father to return Black Hawk and the other prisoners, and he has now sent them home to enjoy their liberty. The Great Spirit has changed the heart of the old chief; has given him a good one. Let the past be buried deep in the earth. Whilst his heart was wrong, he had done many bad things, but now after having traveled through many of the big towns he could see the folly of his past course, and would know how to govern himself in future.

Keokuk then advanced with dignity, his arms folded, to Black Hawk, shook hands with him, and sat down. The other chiefs followed, each taking Black Hawk by the hand, not saying a word till Keokuk broke the silence; then all joined in congratulations. No censure was cast upon the old chief. It was humiliation enough that he was now without honor and power, and indebted for obtaining his liberty to Keokuk, whom he had called a coward for not going to war. Major Garland expressed his pleasure at finding so much good feeling for Black Hawk, and his confidence that all would now live in peace. He reminded Black Hawk that Keokuk was at the head of the nation, that his counsels should be heeded, and that by the terms of the late treaty no band was to exist "under any chief of the late hostile bands." Hereupon Black Hawk rose in violent agitation. He said: "I am an old man. I will not obey the counsels of any one. No one shall govern me." Keokuk at once turned to Black Hawk to allay his indignation, and asked that what he had said might not be remembered, that Black Hawk was too old to say anything good, and that he (Keokuk) was answerable for his good behavior. Black Hawk then recalled his words, and asked to have a black line drawn 
over them. Finally the pipe of peace was passed for all to take a whiff, and in return Major Garland served a glass of champagne. The ceremonies closed with a dance, in which Black Hawk's party did not join, but they retired sullen and dejected.

In the spring following (1834), the Stockbridge Indians, living near Green Bay, descendants of those in Massachusetts to whom Jonathan Edwards was a missionary (17517 ), were moved to send a deputation of their number to the Sacs and Foxes, to persuade them to give up their savage life, have schools, and adopt the ways of civilization. The Rev. Cutting Marsh, a missionary of the American Board of Commissioners for Foreign Missions, accompanied the deputation. He reported as follows:

Keokuk's, the principal village of the Sacs, is situated on the eastern bank of the Iowa river, about twelve miles from its mouth. It contains between forty and fifty lodges, some are forty or fifty feet in length, constructed of bark. The village is at the northern extremity of a delightful prairie extending south and west. There were probably four hundred souls in it.

Upon entering the village, which is formed without any order, my attention was attracted by Black Hawk's lodge. This was enclosed by a neat fence of poles, embracing four or five rods in a circular form. A little gate led into it; around the inside melon vines had been planted. The lodge was constructed of peeled bark. It was perfectly tight, except a hole at the top for the smoke to pass out. At the sides, places were built all around, about three feet from the ground, and mats spread over on which they sat and slept. It was furnished with some dining chairs, which I saw at no other lodge in the nation. I was received politely by the children of Black Hawk, himself and wife being absent. I never before witnessed such a specimen of neatness and good order in any Indian lodge. Although Black Hawk is not permitted to hold any office, it is questionable whether he is not as much respected as the haughty Keokuk who now holds the reins of government.

Winding my way to Keokuk's lodge, which was about fifty feet long, I found him sitting with prince-like dignity in one corner, surrounded by his young men, and wives not less than five. He appeared distant and not disposed to converse, but treated me with politeness and hospitality, and ordered his young men to put out the horses, and supper to be prepared. I found him unwilling to listen to any suggestions respecting the object of my visit, as was the other chief, Pash-e-pa-ha, the Stabber. There was the same unwillingness to hear anything respecting religion, and all made light of it when mentioned in the presence of the latter chief. 
Wapello's village is about ten miles above Keokuk's, is considered to contain thirty lodges. He is a notorious drunkard, and his band follows the example of their chief. At this village I learned that a man murdered his wife a few days before, and then cut off her nose and ears. The Indians are jealous of their wives, and if at such times an Indian cuts off the nose or ears of his wife, no notice is taken of it.

Powesheik's village is upon the Red Cedar, a branch of the Iowa, about ten miles from its mouth. Powesheik is second chief among the Foxes. The village contains about forty lodges and four hundred souls, as Powesheik informed me. He sent one of his young men to inform me I could stay at his lodge, and assigned me a place in it. He is about forty years of age, savage in appearance, and very much debased, as well as all his band. Still he was more willing to converse than either of the chiefs before mentioned. I inquired about the instruction of his young men. He replied that he would like to have two or three educated for interpreters, but he did not want schools, for he wished to have his young men warriors. I inquired if he should not like his young men to make farms. He answered they could work with a hoe, and did not want a plough; they chose rather to hunt for a living than cultivate the ground. He said, "The Great Spirit made us to fight and kill one another when we are a mind to." I showed some young men specimens of Ojibwa writing, and asked if they would not like to have some one come and teach them. They answered, "We do not want to learn; we want to kill Sioux."

Appanoose's village, called Au-tum-way-e-nauk (Perseverance Town), is situated upon the south side of the Des Moines, about one hundred and twenty-five miles from its mouth. This is the most eligible place I met with amongst the Sacs and Foxes for a missionary establishment. It is at a greater distance from the white settlements. The Des Moines, which the Indians call Ke-o-shaw-quah, is a rapid and beautiful river, remarkable for uniformity in width, being generally about forty rods wide. In its banks and bluffs coal is found in abundance. The fine, rolling prairies, covered with a luxuriant growth of grass and flowers of every hue, present a powerful inducement to search for treasures hid in their bosom. This whole region seems to have been formed by nature for agriculture, and I have little doubt will be covered with flocks and herds before another generation shall pass away. But what will become of the Indians?

Besides the villages enumerated there are a number of others consisting of three or four or half a dozen lodges, some of which I visited.

The Sacs and Foxes are strongly attached to their superstitions; I have seen no Indians so much so, and they guard with jealous eare against any change. Their great object is war and hunting, so as to rank among the braves, wear the polecat's tail upon the calves of the legs, and the shau-no-ehun (small bells), and strike the post in the war-dance, and tell the number they have killed in battle. To this there are some exceptions. One of the most striking is Appanoose. He is young and aspiring, and possesses more independence of mind than any of the rest of the chiefs. He expressed a desire to have something done for the improvement of his people. This 
was a great desideratum with his father, Tama, who was a much respected chief. He is anxious himself to receive instruction. He is one of the most kind and gentlemanly Indians I ever met. But he is a drunkard, and my not succeeding to gain his consent to have a school established at his village $I$ attribute to a drunken frolic at the time appointed to bring the matter before him. After he became sober he seemed far less inclined to do anything on the subject than before.

Keokuk in years past manifested a desire to have one of his sons educated, but his mind has been changed. He is altogether under the influence of the traders of the American Fur Company, who are exceedingly hostile to missionary operations. At a council, Colonel William Davenport, commanding officer at Fort Armstrong, strongly urged upon the chiefs to have missionaries. They replied, "We do not want missionaries."

The Sacs and Foxes are in perpetual warfare with the Sioux. Their hunting ground joins on the northwest, and there are mutual complaints of encroachment, which is one great cause of hostility. The Sacs and Foxes are more warlike, and more than a match when equal numbers meet in battle, but the Sioux are the most numerous by far, so that they live in constant fear of each other.*

Previous to the Black Hawk war a few white persons had located themselves on the tract "intended for the use of the half-breeds belonging to the Sac and Fox nations." Among those persons was Samuel C. Muir, an army surgeon, who had lived with a squaw, and who, when such an alliance was forbidden by the Government and required to be terminated, chose to retain it, and left the Government service. He was a native of Scotland, educated at Edinburg, and said, "God forbid that a son of Caledonia should desert his child, or disown his clan." He built the first house at Puck-a-she-tuk (foot of the rapids), where the city of Keokuk stands. The American Fur Company had a trading post here, and built a row of $\log$ houses ("rat row") for their business, Russell Farnham, manager. At the head of the rapids (Ah-wi-petuk), a small settlement of white people built a log house in which Berryman Jennings taught a school in the winter of $1830-31$, the first in Iowa.

Some of the half-breeds were traders, interpreters, and employes of the American Fur Company. Among such was Maurice Blondeau, who had a trading heuse at Flint Hills,

\footnotetext{
-Wis. Hist. Coll., xv, 104.
} 
and died and was buried there in 1829; his name is preserved in that of one of the streets in Keokuk. But most of the half-breeds retained the habits of Indian life. In June, 1834, Congress relinquished the reversionary right of the United States in the tract to those who were entitled to the same under the laws of the State of Missouri, with power to sell their several portions. Questions then arose as to who and how many were the half-breeds, and as to the extent of the tract. Many of the half-breeds had scattered and vanished. There were fraudulent claimants. The questions became entangled and confused. They led to bitter disputes for years, and were not settled without many law suits and long litigation in the courts.

On the first day of June, 1833, the U. S. troops, who up to that time had guarded the Purchase against the incursion of the white people, were withdrawn, and the pioneers of the frontier entered in to make claims and settlements. A transformation of the wilderness commenced. There were some instances of strife and contention among the adventurers for town-sites, mill-sites, belts of timber, and the best lands, but good feeling generally prevailed, and rules and regulations as to claims were agreed upon in the interest of fair dealing and mutual protection. In the absence of established government, people took law and justice into their own hands, and dealt summarily with crime. An instance occurred at Dubuque in the trial and execution of Patrick O'Conner for the murder of George O'Keaf. Appeals were made in vain to the governor of Missouri, and to the judge of the western district of Michigan Territory; they disclaimed jurisdiction. A citizen's court conducted the trial with deliberation and solemnity. A jury was empanelled. All judicial forms were observed. The murder was committed on the 19 th of May, 1834, and the execution took place on the 20th of the following month.

After having been without an established government for a year and one month, Congress interposed and attached the 
territory north of the State of Missouri and between the Mississippi and the Missouri rivers to the Territory of Michigan for temporary government, and gave the inhabitants the same privileges and immunities, and subjected them to the same laws as other citizens of Michigan Territory.

Change in the Name of Our Town.-We are gratified to be able this week to say to our readers that the name of this town (Bloomington) is changed. Henceforth it is to be called Muscatine. We are aware that it will take some time to familiarize every one with the new name-but we think one year will suffice to obliterate the name of Bloomington as associated with our town from the mind of almost every one. The truth is, the town should never have been called by the name of Bloomington. There is a Bloomington in seven or eight of the states, we are confident, and in how many more we know not. Our citizens have been continually perplexed and disappointed at not receiving their letters and papers from abroad at the time they ought to reach here by due course of mail, and many important letters and documents have been given up for lost-when, lo! they would arrire here-marked "Missent and forwarded." Sometimes they would be forwarded from Bloomington, Indiana; sometimes from a town of the same name in Illinois - from the Bloomfields, the Burlingtons, the Bloomingdales, Bloomingtons, and every other town in the United States that was in "Bloom." This great source of difficulty is now, we trust, removed. Muscatine is an Indian name-there is nothing else like it that we know of in any other state. It is euphonious, easily remembered, easily spelt, and very appropriate. It is the name of our county, and we predict that Muscatine, Iowa, will yet make a figure in the world.-Muscatine Journal, June 9, 1849. 
Copyright of Annals of Iowa is the property of State of Iowa, by \& through the State Historical Society of Iowa and its content may not be copied or emailed to multiple sites or posted to a listserv without the copyright holder's express written permission. However, users may print, download, or email articles for individual use. 